OPEN ACCESS

Approved by:

Jochen C. Meier.

Technische Universitat

Braunschweig, Germany

*Correspondence:

Frontiers Editorial Office

editorial.office@frontiersin.org

Specialty section:

This article was submitted to Molecular Signalling and Pathways,

a section of the journal

Frontiers in Molecular Neuroscience

Received: 25 August 2021

Accepted: 25 August 2021

Published: 23 September 2021

Citation:

Frontiers Editorial Office (2021)

Retraction: Different Amyloid- $\beta$

Self-Assemblies Have Distinct Effects

on Intracellular Tau Aggregation.

Front. Mol. Neurosci. 14:764608.

doi: 10.3389/fnmol.2021.764608

\section{Retraction: Different Amyloid- $\beta$ Self-Assemblies Have Distinct Effects on Intracellular Tau Aggregation}

\author{
Frontiers Editorial Office*
}

\section{A Retraction of the Original Research Article}

Different Amyloid- $\beta$ Self-Assemblies Have Distinct Effects on Intracellular Tau Aggregation by Shin, W. S., Di, J., Murray, K. A., Sun, C., Li, B., Bitan, G., and Jiang, L. (2019). Front. Mol. Neurosci. 12:268. doi: 10.3389/fnmol.2019.00268

The journal retracts the 08 November 2019 article cited above.

Following publication, concerns were raised regarding the integrity of the images in the published figures. The authors failed to provide a satisfactory explanation during the investigation, which was conducted in accordance with Frontiers' policies.

This retraction was approved by the Chief Editors of Frontiers in Molecular Neuroscience and the Chief Executive Editor of Frontiers. The authors did not agree to this retraction.

Copyright $\odot 2021$ Frontiers Editorial Office. This is an open-access article distributed under the terms of the Creative Commons Attribution License (CC BY). The use, distribution or reproduction in other forums is permitted, provided the original author(s) and the copyright owner(s) are credited and that the original publication in this journal is cited, in accordance with accepted academic practice. No use, distribution or reproduction is permitted which does not comply with these terms. 